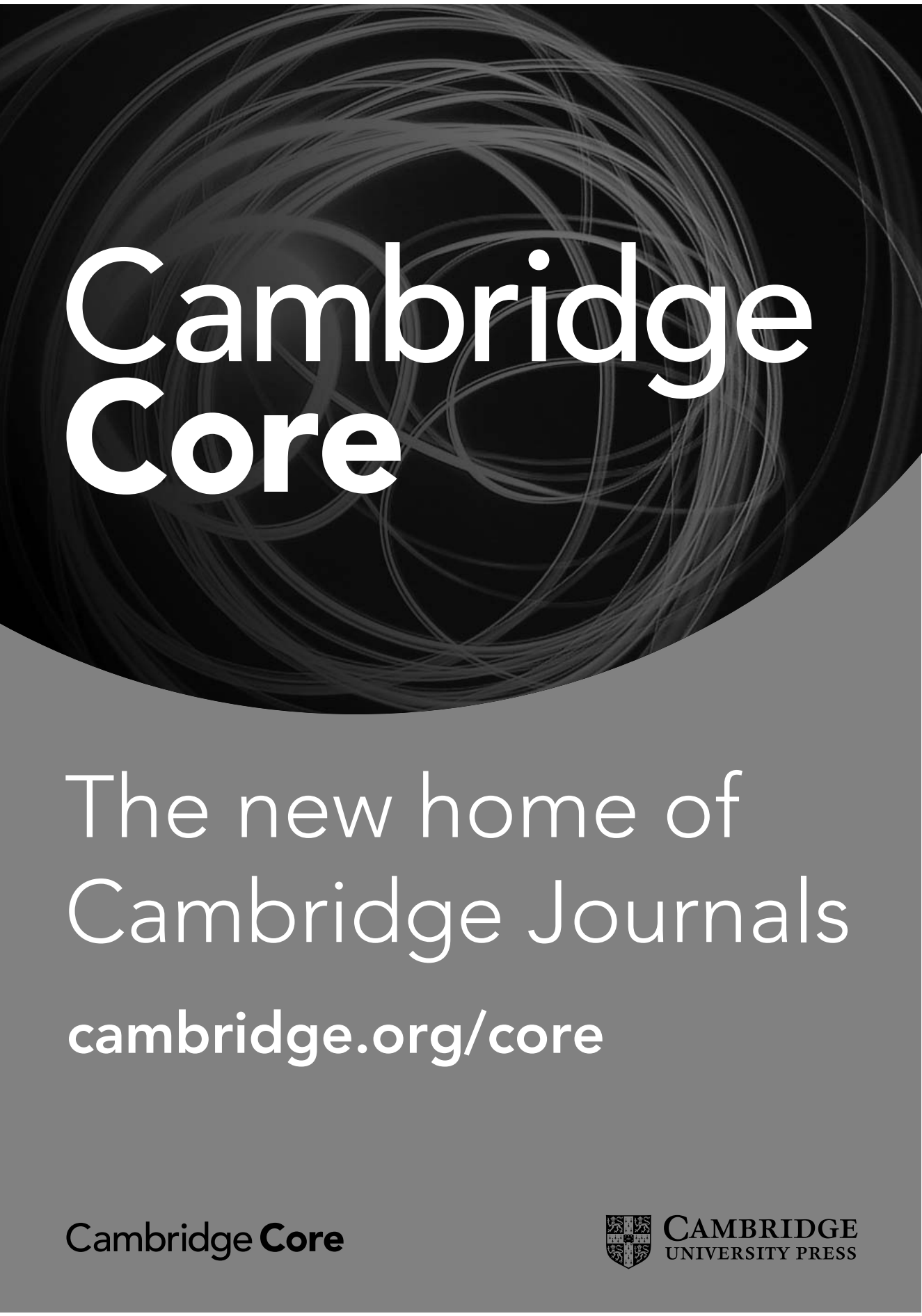

cover design: angela ashton

Cambridge Journals Online

For further information about this journal please

go to the journal website at:

journals.cambridge.org/ntq

$$
\begin{array}{|cc|}
\hline \sqrt{\text { T }}^{\circ} & \begin{array}{c}
\text { MIX } \\
\text { Paper from } \\
\text { responsible sources }
\end{array} \\
\text { FSC } & \text { FSC }^{\circ} \text { C007785 } \\
\hline \text { wowscoory }
\end{array}
$$

CAMBRIDGE UNIVERSITY PRESS 


\section{Drama and Theatre}

\section{Books and Journals from Cambridge University Press}

We are the world's leading publisher in theatre and drama books and journals, with a wide-ranging coverage of the discipline.

Our publishing encompasses theatre history, performance theory and studies, Shakespeare, regional drama and popular theatre.

We publish the journals of the American Society for Theatre Research, the Congress on Research in Dance, and the International Federation for Theatre Research, and provide books for all areas of the market, including university libraries, scholars, students, and theatre enthusiasts.

For further details visit: cambridge.org/core-theatre

\section{Çambridge Core}

